\title{
A Bible translation inspired look at the history and ethnography of the Batswana
}

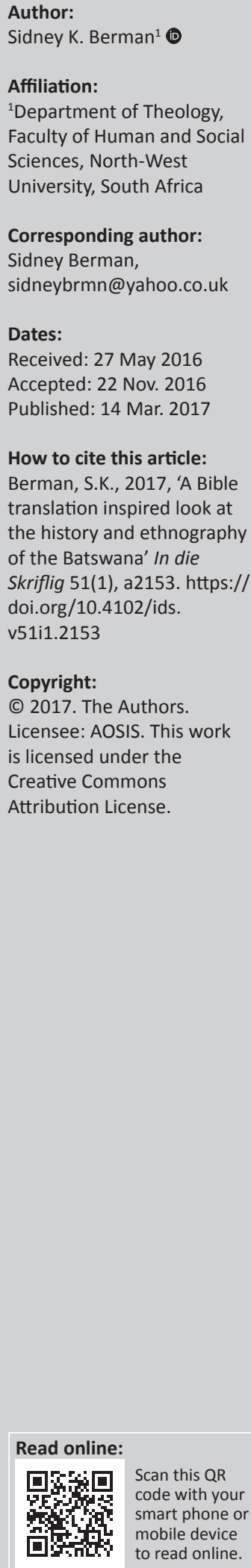

This article's point of departure is that, apart from his or her own understanding of the text, the Bible translator is likely to face difficulties that pertain to the audience's history and ethnography: Some biblical concepts will be difficult or impossible to communicate in the language of the target audience because of mismatches in cultural concepts, limitations of vocabulary in the target language, or the translator's limited understanding of some elements of the target language and culture. Thus, the article examines some aspects of the history and ethnography of the Batswana from the perspective of Bible translation. For illustration purposes, it raises certain issues from the book of Ruth, in particular looking at how the three existing Setswana Bibles rendered or could have better rendered them. The Setswana Bibles in question are those of Moffat, published in 1857, Wookey, published in 1908 and Bible Society of South Africa (BSSA) - once called the Central Tswana Bible, published in 1970. The article proposes explanations that the translator could have given in order to eliminate or reduce the problems. For that reason, the ultimate argument is that the translators could not have translated the three Bibles satisfactorily without the use of explanatory footnotes akin to those of study Bibles. This proposal arose more frequently for Moffat, who appears to have struggled more, not because of his exegetical understanding of the text, but because his audience's familiarity with JudeoChristian concepts was nil. The article is made up of the following topics: the three Setswana Bibles, the Batswana, on the use of Ruth, the Setswana language, means of economic production, the Supreme Being and ancestral spirits, and divination and sorcery.

\section{Introduction ${ }^{1}$}

This article presents some aspects of the history and ethnography of the Batswana, one of the numerous ethnic groups of Southern Africa, from the perspective of Bible translation. The underlying argument is that some traditional aspects of the Batswana's language, culture, religion and worldview posed difficulties and sometimes impossibilities for the translators of the three existing Setswana Bibles, which is named in this article as Moffat, Wookey and BSSA. This is done from an examination of some literature on the history and ethnography of the Batswana, some sources on the history of Bible translation in Setswana as well as some problematic renderings in the three Setswana Bibles that were probably affected by that history and ethnography. Because of scope, the discussion in the article is not exhaustive. The few aspects covered were chosen from my conviction that they best illustrate the problems posed by the history and ethnography of the Batswana to Bible translators. The topics addressed in the article are as follows: the three Setswana Bibles, the Batswana, on the use of Ruth, the Setswana language, means of economic production, the Supreme Being and ancestral spirits, and divination and sorcery.

\section{The three Setswana Bibles}

The three extant Setswana Bibles are Moffat, Wookey and BSSA. The Moffat Bible was translated by the missionary Robert Moffat (1842:444), using the Setlhaping dialect, and was published by the British and Foreign Bible Society (BFBS) in London in 1857. The Wookey Bible was translated by the Reverend Alfred Wookey using a merger of some Setswana dialects, ${ }^{2}$ and was published in London in 1908 by the BFBS (Berman 2014:67). The BSSA Bible was a joint project of several mission organisations, but was eventually overseen and published by the BSSA in 1970. The BSSA Bible was officially referred to as the Central Tswana Bible, because it used Sehurutshe that was classified under the category central Tswana (cf. Jones, Reyneke \& Sandilands 1987:7-8). To avoid a prompt ideological discrimination against the other two Bibles, it is best to name them all by their translators.

2.Contrary to official claims, a linguistic comparison of the three Bibles in their original state demonstrates that Wookey did not use a restricted Setlhaping dialect, but a merger that made Wookey's dialect widely representative of the language. BSSA really had a negligible advantage over Wookey in this regard (cf. Berman 2014:118-121). The argument of a restricted dialect arose once it became apparent that it will be difficult to replace Wookey with BSSA. 


\section{The Batswana}

The Batswana belong to the Sotho-Tswana branch of the Bantu people which consists of the southern Sotho of Basotholand (presently Lesotho), and the northern, eastern or Transvaal Sotho (Brown 1925:19; Schapera 1984:9; Setiloane 1976:12-13). The name Botswana means 'home of the Batswana', even though Botswana is also home to many non-Batswana ethnic groups. Moreover, the country of Botswana has had, for some decades, roughly half the number of Batswana and Setswana speakers as South Africa (Lewis, Simons \& Fennig 2016). They were 3.4 million in South Africa and about 1.7 million in Botswana in 2006 (Lewis et al. 2016; Index Mundi 2014).

Eventually, the Moffat Bible was discontinued, but with the new phenomenon of borders separating Tswana clusters between South Africa and Botswana, the two remaining Bibles caused an ideological split between the Batswana. Those in Botswana preferred the Wookey Bible, while those in South Africa used the BSSA Bible. That was caused by the London Missionary Society's (the organization in charge of Bible translation in Botswana's) decision to replace Wookey with BSSA while the mission societies in Botswana refused to remove Wookey from circulation. Thus, when the BSSA Bible was published, it joined Wookey in circulation rather than replace it - so competition between the two arose.

\section{On the use of Ruth}

The book of Ruth was chosen for illustration, because it abounds in a range of socio-cultural topics that parallel those of Tswana traditional culture. Being set in the agrarian ancient Israel, it has many rich points of interaction with various Sub-Saharan ethnic groups of which Batswana are one (cf. De Waard \& Nida 1973:1; Alfredo 2010:3). ${ }^{3}$ In particular, the book of Ruth has a relatively simple surface structure and a wide range of interesting topics that endear it to a broader range of audiences (cf. De Waard \& Nida 1973; Trible 1992:846). The subject matter of this article, therefore, can become demonstrable to a broad array of audiences. At the same time, in the case of such socio-cultural issues, it has often been assumed that the similarities between ancient Israel and Sub-Saharan African peoples would make the book easy to apply to African contexts. However, this article seeks to demonstrate the limitations of that assumption for a Bible translator, because there are still inherent problematic mismatches between the two sets of contexts.

\section{The Setswana language}

Setswana belongs to the Sotho-Tswana language group, which comprises Setswana, Southern Sotho, Northern Sotho and Lozi (cf. Chebanne et al. 2003:3; Cole 1955:xv; Kruger 2006:3). Grammarians traditionally divided Setswana into four dialects, viz. central division, spoken by the Barolong, Bahurutshe and Bangwaketse; southern division, spoken by Batlhaping and Batlhware; northern division, spoken by the
Bangwato, Batawana and Bakwena (i.e., western Bakwena); and eastern division, spoken by the Bakgatla, Bakwena and minor groups like Batlokwa, Balete, Batlhako, Baphiring, Bakubung and Batloung (Cole 1955:xvi-xviii; cf. also Kruger 2006:3). The divisions that have been featured strongly in the Setswana Bibles are Central Setswana, mostly involving Sehurutshe, and Southern Setswana, mostly involving Setlhaping.

Initially, the dialect of BSSA was considered the most representative of Setswana in the three Bibles. However, in a 1992 revision, the revisers of Wookey, based in Botswana, drastically purged Wookey of many elements of other languages like Pedi and Sotho so that the current version of Wookey is now more representative of Setswana than the current version of BSSA. As observable from the translation of Ruth, BSSA now has more traces of Sotho than Wookey does. Examples include the use of kajeno [today] by BSSA while Wookey uses gompieno (Rt 3:18), and BSSA's use of o phele [live], while Wookey uses o tshele (Rt 3:1). For Wookey, my examination of lexical usage in Ruth yielded just one instance of Sotho influence, viz. the choice dula [sit] for nna (Rt 2:14).

Another updated dialectal difference between BSSA and Wookey pertains to the use of a casual phonology by BSSA that is associated with dialects on the South African side of the border. Wookey uses a more formal linguistic register that is associated with dialects on the Botswana side of the border. That difference seems to contribute to nationalistic preferences whereby the audiences of Botswana prefer Wookey and South African audiences prefer BSSA. For example, BSSA uses tlile instead of tsile [came] (Rt 2:12) and mantsiboeng for maitseboeng [evening] (Rt 2:17), which represent a kind of informal language that seems acceptable for official writing in South Africa, but is regarded as too informal to be used in writing in Botswana. The 1970 translation of BSSA also had lla for lela [cried] (Rt 1:9) and duella for duelela [reward] (Rt 2:12), which it corrected in the 1989 translation. ${ }^{4}$ The minuteness of the differences in the above examples indicates that the ideological division between the Bibles does not relate to meaning in the text. The uniformity of Setswana is of such a nature that users of the different dialects can arguably have no problem understanding each other (Cole 1955:xix).

Batswana's contact with English and Afrikaans speaking people has led to hybridisation of some terms. The vocabulary in the three Bibles suggests that during the eras of Moffat and Wookey, the Batswana had greater interaction with English speaking people than with Afrikaans speaking people. However, the era of BSSA seems to indicate an interaction with Afrikaners - at least as far as the apparent target audience of that Bible is concerned. English loanwords appear in the Moffat and Wookey translations such as $t u$ [two] in Moffat (Rt 1:1) and barele [barley] in Wookey (Rt 1:22). For BSSA, however, where the other two hybridise the English word barley in Ruth 1:22, it hybridises the Afrikaans 4.Cole (1955:49) discusses this type of grammatical elision. 
word gars to make garase. Where Wookey follows the English pronunciation to have Baebele [Bible] on the cover, BSSA follows the Afrikaans pronunciation to have Beibele. With regard to the examples above, there is a Setswana word for 'two', namely babedi. There is none for 'barley' or 'Bible'. The list of officially accepted Setswana vocabulary in Tswana Terminology and Orthography (South Africa Department of Bantu Education 1972:37) prefers hybrid words from Afrikaans rather than from English, because, as per the explanation, they are more popular than their English counterparts, and Afrikaans phonology is often closer to Setswana than English.

Moffat's choices, $t u$ [two] $(1: 1 ; 3: 1)$ sekes [six] $(3: 15,17)$ seven (4:15) and ten $(1: 4 ; 4: 2)$ instead of babedi, thataro, supa and lesome, respectively, must have arisen from a decision to demonstrate arithmetic to the Batlhaping that he was teaching them in his elementary schools. Contemporarily, they sound amateurish in written form and inappropriate for Scripture. However, it is highly improbable that Moffat did not know how to count up to ten in Setswana, having translated far more complex Setswana words to produce all of the New Testament and a portion of the Old Testament. Probably, Moffat was wary of teaching the Batswana numbers in Setswana, because the numbers that they have to deal with were be much longer and more abstract than the ones they were accustomed to. Along the same lines, another missionary and translator, Sandilands (1953) observes:

The old Bantu system of numeration was logical and adequate for the limited demands of a pastoral and unlettered people, but it is too clumsy to be an effective instrument for modern trading or money matters. Especially is this so in the case of numbers upwards of twenty; the English numerals are increasingly being used, often with modifications of pronunciation. (E.g. dikgomo di le naene; di le sekestini; di le toenteterii, 9, 16, 23 oxen). (p. 110)

Therefore, it appears that Moffat was acquainting his audience with reading numbers in English so that larger ones are easy to comprehend. In that case, it is likely that the numbers sounded appropriate to Moffat's audience. Nevertheless, if the translator had the liberty to insert an explanation in a footnote, later audiences that were more arithmetic-literate could perhaps find less fault with the transliteration.

\section{Means of economic production}

At the beginning of the period of Bible translation for the Batswana, namely in the 1820's, the Batswana clusters depended on livestock rearing, crop production and hunting game for economic means as per tradition. That was during the period of Moffat's translation work. They practiced backyard gardening using hand held hoes (cf. Morapedi 1999). The farmer was rarely able to produce enough even for the family's private consumption (Breutz 1956:53; 1968:77). Around the time of Moffat's publication, certain changes ensured that the Batswana would be fully acquainted with the concept of large crop fields outside of the village. First, they started to seek short-term employment on European farms at the time of harvest, whereupon they would get a good salary. Many men and women joined in this practice where they were paid with enough maize or other crops to feed their families for almost a whole year (Breutz 1968:63, 78). The second development was that they forsook backyard gardening in favour of large fields outside the village, using European farming methods and modern tools (Morapedi 1999:198-199; Schapera \& Comaroff 1991:15). A hand-held hoe in the place of draughts was probably to blame for the Batswana's traditional preference for small gardens.

The development discussed above, namely exposure to the idea of large farms, would bridge the knowledge gap for the Batswana as far as understanding the Israelite idea of gleaning was concerned. Surely, Ruth, the stranger, could not pick crops in someone's backyard, and Boaz would not need so many servants to harvest his backyard garden over such a long period of time. The phenomenon of large farms in the Batswana's new world was a rich point of intersection that could help prevent a misunderstanding of the idea of gleaning in Ruth 2 and 3. A knowledge gap, nevertheless, could manifest from the fact that Ruth did not help in the harvest, took someone's crop without asking and was evidently not bargaining for the food she was picking. She seemed entitled to pick crops in a stranger's field without paying. The audience will need to have the information on Israelite gleaning in order to avoid distraction or misinterpretation. It would be helpful for all the three Bibles to explain in the translation what gleaning is. The renderings given, namely ronopa (Moffat and Wookey) and sela (BSSA), simply mean 'pick', and do not even indicate what she was picking or from what storage she was picking it. This context encompasses even the harvesters' behaviour and how Boaz really wanted them to respond to Ruth's actions. For example, how did gleaners and harvesters relate with each other? How were they expected to relate?

Like the new phenomenon of large crop farms, sojourning for economic purposes (go jaka) was also to become part and parcel of the Batswana's culture. It was arguably the most radical socio-cultural change of the time, because individuals would habitually travel to live far away from their communities for about a year and more. South African mining companies recruited Batswana males annually, giving contracts of 9-18 months (Breutz 1968:79). Prior to that, leaving one's community voluntarily to be employed and temporarily live in a foreign community was an unacceptable concept. The sojourning was less harsh when the victim joined a community of fellow Batswana, because the Batswana clusters claimed kin ties with each other. Still, it only occurred during desperate times, for example, when the ancestors of Moseki, Marokhu and Dinokwane wards attached themselves to the Bangwato in search for food after leaving their Bakwena community (Schapera 1952:23). They came as single families and sometimes as individuals, but they eventually settled permanently. Thus, the Batswana clusters were familiar with the concepts of being uprooted, temporarily sojourning or permanently resettling as individuals, families and whole communities, but these were 
prompted by famine, political fall-outs and marauding tribes (cf. Moffat 1889:74-92; Sundkler \& Steed 2000:427; Schapera 1952:20, 23). Otherwise, the Batswana regarded a sojourner as a desperate individual who risked being pitied, denigrated and/or reduced to the state of a servant or beggar. The pattern of temporary labour in a foreign land would later take definitive shape among the Batswana around 1900 (cf. Wilmsen 2009:30). That was when the South African mines started to make the Batswana clusters their fixed source of labour - about a decade before the publication of Wookey.

Yet, Moffat's rendering of the concept of sojourning indicates that it was a difficult concept for the Bible translator to accurately communicate to the Batswana (Rt 1:1). Moffat clearly avoided the common term jaka while Wookey and BSSA used it - Moffat chose the term tlolatlola [hop around]. Possibly, the usage of the word jaka evolved as the concept itself evolved in practice among the Batswana so that, by the time of Wookey and BSSA, the word or concept was no longer problematic. Apparently, the word jaka triggered an understanding in the minds of the Batswana that Moffat felt did not match the actions of Naomi's family. Perhaps the Setswana version of jaka was disproportionately denigrating.

In any case, Moffat constructed a term, namely tlolatlola, to translate 'sojourn', but all indications are that he produced it by accident - he rather misspelt tholatlhola, a word that could connote 'spend day after day' or 'check every once in a while'. According to Cole (1955:217), the frequentative form that Moffat created here would signify 'that the action is carried out frequently or repetitively, often with the added idea of indiscriminate, careless, aimless or inopportune action'. The frequentative is formed by reduplicating the verb stem. Possibly, by reduplicating this verb stem, Moffatt may have thought that he was conveying to his readers the idea that Elimelech's family aimlessly spent day after day in Moab. In that scenario, Moffat's European accent apparently caused him to pronounce the phoneme $t l$ - as an aspirated explosive (i.e. as tlh-) rather than as an ejective explosive (cf. Cole 1955:21). As a result, Moffat's readers could interpret that Elimelech's family hopped all over the country of Moab. Yet, even if we were to correct Moffat's misspelling, the term tholatlhola for 'spend a day' or 'check every once in a while' does not profile 'sojourn', which should have triggered the notions of foreignness, stigma, economic disadvantage and dependency in the mind of the Setswana audience. ${ }^{5}$ Where Moffat feared that a rendering may be misunderstood, it would have been advantageous to him and the audience had he had the liberty to explain the rendering further in a footnote.

\section{The Supreme Being and ancestral spirits}

The Batswana acknowledged a Supreme Being, Modimo, whom, like the biblical God, was greater in power than

\footnotetext{
5.Brown's dictionary (1980:544) also translates the word sojourn erroneously as tholathola. In its preface, it says that the dictionary maker 'learned much from those of the in its prectioce, it says that the dictionary maker those of the preceding generation, men such as Moffat, Ashton, Livingstone an Hughes, who had pioneered the study of the language' (Brown 1980:iii). Thus, Moffat's writings probably influenced decisions made in Brown's dictionary. Moreover, the word tholat/hola is not recorded in the other Setswana dictionaries (e.g. Dent 1992:182; Snyman, Shole \& Le Roux 1990:184)
}

everyone and everything in existence - both living and nonliving (cf. Brown 1925:113; Lichtenstein 1973:72). Next in divine hierarchy were medimo, that is the demi-gods who were super humans created first by Modimo, viz. Loowe, Tintibane, Matsieng, Thobega, Nape and Tshosa (Breutz 1956:76; Brown 1925:113; Schapera 1984:59). They had absolutely no involvement in people's lives and were only mentioned in folk tales and creation myths. Last in the hierarchy were the badimo, namely the spirits of ancestors which continue a semi-human life after death (Breutz 1956:76).

Modimo is the creator of all things, which gives Modimo the title mothodi or mmopi (Setiloane 1976:78). While little else was said or known about Modimo, it appears that, traditionally, the active powers of Modimo were primarily associated with the weather, and it could send or withdraw rain (cf. Schapera \& Comaroff 1991:53). Therefore, the statements there was famine in the land (Rt 1:1) and Yahweh had taken care of his people by giving them bread (Rt 1:6), can evoke both the traditional and contemporary Setswana views that Modimo is responsible for drought and abundance. Moreover, the Batswana were apt to identify many more instances of 'the hidden hand of God' such as is prominent in the story of Ruth.

However, even if they would credit Modimo for the drought, the Batswana would certainly engage in divination to try and establish why Modimo had brought drought in that instance, and would subsequently engage in mystic rituals to appeal to the favours of Modimo. In the time of the missionary and translator, Robert Moffat, a diviner medicine man diagnosed to the community that Moffat, on account of his colour and long beard, was a bad omen that had brought about the drought. One of the proposed solutions was to expel Moffat by force, but he refused and insisted that they should rather kill him (Moffat 1842:327-328). Only belief in the new mysterious Christian Supreme Being partly helps Batswana explain why unpleasant things may happen without explicable cause. In the new so-called syncretistic context, when the diviner cannot explain the cause of a problem, she or he attributes it to 'the will of God' (Ullin 1975:98).

Nonetheless, the initial Modimo of the Batswana was different in certain important ways. For example, Modimo is genderneutral, impersonal and fits the pronoun it rather than she or he (cf. Cole 1955:75). Modimo is a class 2 noun and takes the impersonal plural prefix me-, not the personal $b a$ - or bo-. Moreover, the biblical Modimo interacted extensively with his subjects whilst the Batswana's Modimo was quite distant from the day-to-day affairs of human beings (cf. Brown 1925:114; cf. Schapera 1984:59). The difference probably posed a conceptual challenge to an audience who could not imagine talking to God or being directly attended to by Modimo.

In that respect, it should have been very difficult for the target audience of the first Setswana Bible (Moffat 1857) to recognise Modimo once it was presented as the JudeoChristian Modimo (cf. Ntloedibe-Kuswani 2006:78-97). The trend of making study Bibles should have made more sense 
in that era than today, but due to methodological conventions, footnotes were regarded as taboo. They were considered as tampering with the original Word of God (cf. Makutoane \& Naude 2009:83). A concise explanation could have contributed towards bridging the gap between the two concepts of Modimo. Footnotes on this concept could address Ruth 1:6-9, for example, where the narrative starts to reference the personal name of God (rendered as 'Jehova' by Moffat, 'Jehofa' by Wookey and 'MORENA' by BSSA in their attempts to translate God's personal name 'Yahweh'). ${ }^{6}$ Ruth 1:6 reports that Naomi had heard of how God, addressed with the personal name Yahweh, had provided for her people. The footnotes could explain that Yahweh (or whichever name a particular translator chose) was the proper (personal) name of God by which people could differentiate between God and other gods. Modimo, on the other hand, was the title. Therefore, whilst different ethnic groups call God by various titles in their own languages, God's personal name would not change.

The traditional religion of the Batswana was the veneration of the spirits of dead ancestors, namely badimo. That religion was observable only during weddings, difficulties, misfortune, disobedience of children and community disasters (Breutz 1956:76). Females were buried with farm hand-tools and seeds while males were buried with weapons so as to continue life as usual underground as badimo (Schapera 1984:59). The badimo could be congratulated for taking care of the people, or be chastised (Breutz 1956:76). People also occasionally left food and drinks for the badimo to eat, such as a sauce of meat and potatoes the day before a wedding or ears of sorghum on their fields after harvesting (Breutz 1956:76). The above sentences only serve to illustrate how the traditional religion of the Batswana was different from the one they were introduced to in the book of Ruth where, instead of ancestral spirits, God related directly with Naomi and her family. In the other verses in Ruth, Naomi blesses the daughters-in-law, praying that Jehova would show them kindness and lead them to peace and prosperity. A footnote in those instances could explain that in the case of the Israelites, God was directly and intensely involved in human affairs just like the badimo were in the case of the Batswana. In other words, God did not depend on the dead ancestors of Israel to deal with the people. Wookey and BSSA most likely did not need a footnote on the identity and activeness of Modimo, because, by then, they already understood and embraced the biblical concept of Modimo.

The Bibles' audiences would probably be uninterested in forsaking their badimo in preference for Naomi's Jehofa. Therefore, the translator, who brought the Bible precisely to convince the audience otherwise, could explain God's universal plan of salvation from the time of creation as it moved from general to specific. This plan was to introduce the world to the worship of God alone as could be seen in the call of Abram and the Great Commission, which are two of the topics that could be mentioned in the footnote. Noting that the Batswana's refusal of Moffat's preaching stopped abruptly when they started reading Scripture for themselves (Moffat 1842:495-497), one must argue that if he had inserted his explanations in the Bible itself, he could have achieved faster his desire to see the Batswana discard the badimo and focus on Modimo alone.

\section{Divination and sorcery}

The Batswana ascribed catastrophes of the community to the displeasure of the badimo, but personal mishaps and hardships were traditionally blamed on both sorcery and the badimo. Among these two causes of personal evil, attribution was severely skewed towards sorcery. No kind of disaster, disease or failure was ever ascribed to natural causes or personal irresponsibility (Breutz 1956:71; Brown 1925:137). A traditional doctor (ngaka), namely a specialist in magic, ritual and medicine was invariably consulted to investigatethe nature and causes of sickness; the reasons for a person's death; the whereabouts of missing stock; the prospects for a journey; the meaning of unexpected objects and occurrences; or what the future has in store (Schapera 1984:64).

In Ruth 1:3 and 5, the deaths of Naomi's husband and sons are reported respectively. Automatically, it would occur in the minds of Moffat's audience that Naomi should immediately call a medicine man to investigate the cause of deaths as soon as it happens. The cause could include being under the curse of an aggrieved elderly person or ancestral spirits, but far greater were the chances that she would be found to be bewitched by a jealous friend or relative. She would bewitch back the murderer and additionally engage in some form of ritual to enact mystic protection and prevent the next death. To omit the witchcraft element from the story would surely cause wonder or speculation on the audience's part. At best, it could be speculated that the story was being selective for purposes of a main aim as well as to avoid distractions. At worst, the audience could make additions to the story in accordance with their own worldview in order to make sense of the story. That would effectually distract the translator's rendering of the narrative.

A footnote could reference the contrast between the two worldviews and explain that unlike in Tswana traditional belief, Naomi's religion did not ascribe personal negativity to witchcraft or curses. Instead, Naomi conveys in Ruth 1:13 that people primarily held that it is God's initially incomprehensible dealings with people that nonetheless have an ultimately benevolent motif. The story of Job would be a good example to cite in the footnote. In the present text, Naomi's losses led to the birth of the ancestor of the nation's messiah (Rt 4). In that community, people believed that God, who was their personal protector, had absolute mystic powers over their enemies. Thus, an individual usually felt insulated from evil powers of sorcerers. Second to that was the belief that God punishes disobedience and rewards obedience. The story of the death of David's first infant, son with Bathsheba, comes to mind. 
According to the traditional religion of the Batswana, good fortune was not acquired or maintained by chance or personal initiative (Brown 1925:137). Indeed, the Batswana had a saying, lesego le le senang more le a tloga [fortune without a charm is only fleeting] (Brown 1925:139). Thus, in that worldview, it is impossible that Ruth could succeed in turning her life around the way she did in Ruth 4, without the use of mystic rituals and charms. The translator of the narrative would do well to address in a footnote the incredulity of the audience in such instances.

\section{Conclusion}

This article argued that, even if a translator could make a faultless exegetical examination of the biblical text, she or he would still face important translational problems arising from the target audience's language, sociocultural practices, religion and worldview. That is because there are mismatches between these elements of the target audience and those of the source text or ancient Israel, which can be difficult or impossible to surmount. That problem pertains to the next stage of the translation process after exegesis, namely communication of the text in the target language. The article demonstrated the problem using the text of Ruth in the three extant Setswana Bibles, namely Moffat, Wookey and BSSA. Because Moffat's audience had no previous acquaintance with Judeo-Christianity, they would be the most difficult of all three audiences to translate for. Suggestions were made for the best way each problematic aspect could be translated with the most common proposal being footnotes.

\section{Acknowledgements Competing interests}

The author declares that he has no financial or personal relationships which may have inappropriately influenced him in writing this article.

\section{References}

Alfredo, J.M., 2010, $70 \pi$ and Ikharari: The Book of Ruth from a Lomwe Perspective, unpublished doctoral dissertation, Stellenbosch University, Stellenbosch.

Berman, S.K., Analysing the Frames of a Bible: The Case of the Setswana Translations of the Book of Ruth, University of Bamberg Press, Bamberg.

Bible Society of South Africa [BSSA], 1970, Beibele, Bible Society of South Africa, Cape Town.

Breutz, P.L., 1956, Ethnological Publications: The tribes of Mafikeng district, Department of Native Affairs, Pretoria.

Breutz, P.L., 1968, Ethnological Publications: The tribes of the districts of Taung and Herbert, Department of Native Affairs, Pretoria.
British and Foreign Bible Society [BFBS], 1857, Bibela ea boitsepho ee cutseng kholagano e kholugolu le e nca, tse ri hetolecoeng mo puon ea Sechuana, British and Foreign Bible Society, London.

British and Foreign Bible Society [BFBS], 1908, Bibela ee boitshepo, British and Foreign Bible Society, London.

Brown, J.T., 1925, Among the Bantu nomads: A record of forty years spent among the Bechuana, a numerous and famous branch of the central south African Bantu, with the first full description of their ancient customs, manners and beliefs, Seeley Service, London.

Brown, J.T. 1980. Setswana Dictionary: Setswana-English and English-Setswana, Pula Press, Johannesburg.

Chebanne, A., Mokitimi, M., Matlosa, L., Nakin, R., Nkolola, M. W., Mokgoatshana, S. and Machobane, M., 2003, The standard unified orthography for Sotho/Tswana languages: (Botswana, Lesotho, Namibia, South Africa, Zambia and Zimbabwe) Centre for Advanced Studies of African Society, Cape Town. (Monograph Series, 31).

Cole, D.T., 1955, An introduction to Tswana grammar, Longmans \& Green, London.

De Waard, J. \& Nida, E.A., 1973, A Translator's Handbook on the Book of Ruth, United Bible Societies, London, New York.

Dent, G.R., 1992, Compact Setswana dictionary, Shuter \& Shooter, Pietermaritzburg, Cape Town, Johannesburg.

Index Mundi, 2014, Botswana population, viewed 26 May 2016, from http://www. indexmundi.com/botswana/population.html

Jones, J.D., Reyneke, J.L. \& Sandilands, A. 1987, The History of the Setswana Bible, Bible Society of South Africa, Cape Town.

Kruger, C.J.H., 2006, Introduction to the morphology of Setswana. Lincom studies in African linguistics, Lincom Europa, Munich.

Lewis, M.P., Simons, G.F. \& Fennig, C.D. (eds.), 2016, Ethnologue: Languages of the world, 19th edn., Summer Institute of Linguistics International, Dallas, Texas, viewed May 26 2016, from http://www.ethnologue.com/

Lichtenstein, W.H.C., 1973, Foundation of the Cape: About the Bechuanas, A.A. Balkema, Cape Town

Makutoane, T.J. \& Naude, J.A., 2009, 'Colonial interference in the translations of the Bible into southern Sotho', Acta Theologica, suppl. ser. 12, 79-94.

Moffat, R., 1842, Missionary labours and scenes in southern Africa, Paternoster-Row, London.

Morapedi, W.G., 1999, 'Migrant labour and peasantry in the Bechuanaland protectorate, 1930-1965', Journal of Southern African Studies 25(2), 197-214.

Ntloedibe-Kuswani, G.S., 2006, 'Translating the divine: The case of Modimo in the Setswana Bible', in M.W. Dube (ed.), Other ways of reading: African women and the Bible, pp. 78-97, World Council of Churches Publications, Atlanta, Geneva.

Sandilands, A., 1953, Introduction to Tswana grammar, Tigerkloof, Cape Town.

Schapera, I., 1952, The ethnic composition of Tswana tribes, London school of economics and political science, University of London, London, New York. (Monographs on Social Anthropology, 11).

Schapera, I., 1984, The Tswana, Kegan Paul International, London.

Schapera, I. \& Comaroff, J.L., 1991, The Tswana, rev. edn., Kegan Paul International, London, New York.

Setiloane, G.M., 1976, The image of God among the Sotho-Tswana, A.A. Balkema, Rotterdam.

Snyman, J.W., Shole, J.H.J. \& Le Roux, J.C., 1990, Dikisinare ya Setswana / English Afrikaans Dictionary Woordeboek, Via Afrika Limited, Pretoria.

Sundkler, B. \& Steed, C., 2000, A history of the church in Africa, Cambridge University Press, Cambridge.

South Africa Department of Bantu Education, 1972, Tswana terminology and orthography, no. 3, The Government Printer, Pretoria.

Trible, P., 1992, 'Ruth, Book of', in D.N. Freedman, G.A. Herion, D.F. Graf, J.D. Pleins, et al. (eds.), The Anchor Bible Dictionary, vol. 5, pp. 842-847, A.B.D. Doubleday, New York, London, Toronto, Sydney, Auckland.

Ullin, P.R., 1975,'The traditional healer of Botswana in a changing society', Botswana Notes and Records 7, 95-102.

Wilmsen, E N., 2009, 'The real Bushman is the male one: labour and power in the creation of Basarwa ethnicity', Botswana Notes and Records 22, 21-35. 